\title{
Pregnancy-associated plasma protein A as a predictor of all-cause mortality and cardiovascular events in patients with chronic kidney disease: a meta-analysis of prospective studies
}

\author{
Yuehua $\mathrm{Li}^{1}, \mathrm{Xv} \mathrm{Meng}^{1}$, Chenghui Zhou ${ }^{2}$, Xianliang Zhou ${ }^{1}$
}

\begin{abstract}
'Department of Cardiology, State Key Laboratory of Cardiovascular Disease, Fuwai Hospital, National Center for Cardiovascular Diseases, Chinese Academy of Medical Sciences and Peking Union Medical College, China

2Department of Anesthesiology, State Key Laboratory of Cardiovascular Disease, Fuwai Hospital, National Center for Cardiovascular Diseases, Chinese Academy of Medical Sciences and Peking Union Medical College, Beijing, China
\end{abstract}

Submitted: 3 May 2017

Accepted: 16 July 2017

Arch Med Sci 2020; 16 (1): 8-15

DOI: https://doi.org/10.5114/aoms.2020.91283

Copyright $\odot 2019$ Termedia \& Banach

\section{Abstract}

Introduction: The aim of the study was to assess the association of elevated serum pregnancy associated plasma protein A (PAPP-A) and the risk of all-cause mortality, cardiovascular events and mortality due to infection in patients with chronic kidney disease (CKD).

Material and methods: We systematically searched the Medline database up to March 2017. A random effects model was used to pool the relative risks (RRs) and their 95\% confidence intervals (Cls). Sensitivity analysis and subgroup analysis were performed to explore the potential sources of heterogeneity.

Results: Six studies involving 2034 subjects were included. The pooled RRs for the risk of all-cause mortality and cardiovascular events were 1.50 (95\% Cl: 1.17-1.92), 1.26 (95\% Cl: 0.95-1.69), respectively. Sensitivity analysis by excluding each individual study showed no influence on the main results. Subgroup analysis showed that age, male proportion, follow-up term, and assay methods were not modifiable factors.

Conclusions: Our study suggests that elevated serum PAPP-A is associated with the risk of all-cause mortality in patients with CKD.

Key words: pregnancy-associated plasma protein A, all-cause mortality, chronic kidney disease, meta-analysis.

\section{Introduction}

Chronic kidney disease (CKD) is very prevalent, affecting $8-16 \%$ of the population globally. Patients with CKD suffer from high mortality and morbidity [1]. Previous studies have indicated that cardiovascular events are the leading cause of death for patients with CKD [2-4]. Current data show that CKD or end-stage renal disease (ESRD) and cardiovascular diseases share some common mechanisms, such as accelerated inflammation and atherosclerosis [5-7].

Pregnancy-associated plasma protein A (PAPP-A) is a newly discovered zinc-binding metalloprotein, which has been suggested to be

\author{
Corresponding authors: \\ Yuehua Li MD, PhD \\ Xianliang Zhou MD \\ Department \\ of Cardiology \\ State Key Laboratory \\ of Cardiovascular Disease \\ Fuwai Hospital \\ National Center for \\ Cardiovascular Diseases \\ Chinese Academy \\ of Medical Sciences \\ and Peking Union \\ Medical College \\ Beijing 100037, China \\ E-mail: liyuehuafw@163.com, \\ xlzhou-fw@hotmail.com
}


involved in the processes of inflammation and atherosclerosis [8-10]. PAPP-A primarily acts as a protease cleaving inhibitory binding proteins of insulin-like growth factors [11]. In vitro studies have indicated that proinflammatory cytokine tumor necrosis factor $\alpha$ and interleukin $1 \beta$ are powerful stimulators in inducing the expression of PAPP-A [8, 10, 12]. In vivo studies have suggested that a mouse model with PAPP-A gene knock-out could resist the accelerated progression of atherosclerosis, whereas over-expression of the gene of PAPP-A in the mouse model could accelerate progression of atherosclerosis [8, 13]. Clinical studies have shown that PAPP-A is not only an acute and sensitive biomarker for the diagnosis of acute coronary syndrome [14-16], but also acts as a prognostic indicator of all-cause mortality and combined cardiovascular events for patients with coronary heart diseases [1725], which was systematically reviewed in our previous meta-analysis [24].

It remains unclear whether elevated PAPP-A was a predictor in patients with CKD. Some previous studies have shown that PAPP-A is an independent risk factor associated with increased mortality and cardiovascular events, while others have indicated no association in patients with CKD [26-32]. So we combined all available prospective studies and conducted a meta-analysis to assess the association of elevated serum PAPP-A and the risk of all-cause mortality and cardiovascular events in patients with CKD.

\section{Material and methods}

\section{Search strategy}

We performed this meta-analysis according to the Meta-analysis of Observational Studies in Epidemiology (MOOSE) guidelines [33]. Two authors (Yuehua Li and Xv Meng) identified articles through searching MEDLINE from 2000 to Mar 2017. The key word used in the search was "PAPP-A". No language restriction was applied for searching and study inclusion.

\section{Study selection and outcomes}

The inclusion criteria were determined as follows: (1) prospective studies design; (2) provided the referent (the lowest) and highest levels of serum PAPP-A, or the cut-off value of PAPP-A; (3) provided the unadjusted or multivariable adjusted relative risks (RRs) and their corresponding 95\% confidence intervals (Cls).

The primary outcome was all-cause mortality. The second outcome was cardiovascular events, which were defined by each individual study, including cardiovascular death, myocardial infarction, revascularization, sudden death, and so on.

\section{Data extraction}

Data extraction was conducted by two independent authors (Yuehua Li and Xv Meng). Discrepancies were resolved by group discussion. The extracted data included the name of the first author, publication year, sample size, number of events, male proportion, mean age, duration of follow-up, assay methods for measuring serum PAPP-A, cutoff value of serum PAPP-A, outcomes, adjusted covariates and RRs and their corresponding 95\% Cls. We extracted the most fully adjusted RRs for the highest level of PAPP-A compared with the lowest one. If the multivariable adjusted RRs were not provided, we extracted the unadjusted ones.

\section{Statistic analysis}

We considered the hazard ratios or odds ratios as RRs in prospective studies. Compared with the lowest category of PAPP-A, the pooled RRs and their $95 \% \mathrm{Cl}$ of the highest category were estimated by a fixed-effect model to incorporate the inter-study variability. We extracted data from the highest quartile if provided by $>2$ quartiles. If there was significant heterogeneity among studies, we used the random-effect model. The heterogeneity was assessed by the $\mathrm{Q}$ statistic, $P$ and $p$-value. $R^{2}>50 \%$ was considered to indicate significant heterogeneity among the trials [34]. We tried to explore the potential source of heterogeneity by conducting sensitivity analysis and subgroup analysis. We performed the sensitivity analysis by removing each individual study to evaluate the study's effects on the summary estimate. The subgroup analysis was performed by specified study characteristics, such as age ( $\geq 65$ or $<65$ years), male proportion ( $\geq 60 \%$ or $<60 \%$ ), the follow-up term ( $\geq 5$ or $<5$ years), and assay methods (Time Resolved Amplified Cryptate Emission (TRACE) or others).

We assessed publication bias by Begg's funnel plot and Egger's regression test [35]. A two-sided $p$-value $<0.05$ was considered to be significant. All of these analyses were completed by STATA software (10.0 version, Stata Corporation, TX, USA).

\section{Results}

\section{Search results}

We identified 1866 articles in the initial research. Among these studies, 1838 were excluded based on the title and abstract due to being experimental studies, reviews and non-relevant. Twenty-eight potential studies were selected for detailed accession. We further excluded 22 for the following reasons: not prospective design $(n=3)$, not relevant to the outcomes $(n=18)$, did not provide RRs or their $95 \% \mathrm{Cl}(n=1)$. Finally, 6 potential prospective studies concerning 2034 participants 
and 792 events were included in our meta-analysis [26, 28-32]. Among them, 5 trials have reported the endpoint of all-cause mortality $[26,28-30$, $32]$, and 4 have reported the endpoint of cardiovascular events [26, 29-31].

\section{Study characteristics}

The characteristics of the included studies are presented in Table I. All the studies were conducted in Europe. The sample size ranged from 130

Table I. Characteristics of included studies

\begin{tabular}{|c|c|c|c|c|c|c|c|c|c|}
\hline Study & Year & Country & $\begin{array}{l}\text { Men } \\
\%\end{array}$ & $\begin{array}{l}\text { Mean } \\
\text { age }\end{array}$ & $\begin{array}{l}\text { Fol- } \\
\text { low-up } \\
\text { term }\end{array}$ & $\begin{array}{l}\text { No. of } \\
\text { sub- } \\
\text { jects }\end{array}$ & $\begin{array}{l}\text { No. of } \\
\text { death }\end{array}$ & $\begin{array}{l}\text { No. } \\
\text { of CV } \\
\text { vents }\end{array}$ & Type of CKD \\
\hline $\begin{array}{l}\text { Lauzurica } \\
\text { et al. [31] }\end{array}$ & 2005 & Spain & 65.7 & 53.14 & $\begin{array}{l}49.3 \\
\text { months }\end{array}$ & 178 & NA & 27 & Renal transplant \\
\hline $\begin{array}{l}\text { Astrup } \\
\text { et al. [26] }\end{array}$ & 2007 & Denmark & 70.88 & 61 & $\begin{array}{c}10.1 \\
\text { years }\end{array}$ & 197 & 48 & 41 & $\begin{array}{c}\text { Diabetic } \\
\text { nephropathy }\end{array}$ \\
\hline $\begin{array}{l}\text { Etter } \\
\text { et al. [32] }\end{array}$ & 2010 & Swizerland & 65.3 & 70 & $\begin{array}{l}17.5 \\
\text { months }\end{array}$ & 170 & 23 & NA & Haemodialysis \\
\hline $\begin{array}{l}\text { Kalousova } \\
\text { et al. [29] }\end{array}$ & 2012 & Czech Republic & 54 & 63.2 & 5 years & 261 & 146 & 71 & Haemodialysis \\
\hline $\begin{array}{l}\text { Kalousova } \\
\text { et al. [30] }\end{array}$ & 2014 & Germany & 55 & 66 & 4 years & 1098 & 534 & 398 & $\begin{array}{c}\text { Diabetic } \\
\text { haemodialysis }\end{array}$ \\
\hline $\begin{array}{l}\text { Jefferies } \\
\text { et al. [28] }\end{array}$ & 2015 & Finland, UK & 67 & 65.3 & 407 days & 130 & 25 & NA & Haemodialysis \\
\hline Study & \multicolumn{2}{|c|}{ PAPP-A assay method } & \multicolumn{3}{|c|}{ Cut-off value [mIU/l] } & \multicolumn{2}{|c|}{ Outcomes } & & Adjusted variables \\
\hline $\begin{array}{l}\text { Lauzirica } \\
\text { et al. [31] }\end{array}$ & \multicolumn{2}{|r|}{ DSL ELLISA } & \multicolumn{3}{|c|}{1.82} & \multicolumn{2}{|c|}{$\begin{array}{c}\text { Cardiovascular event, } \\
\text { chronic allograft } \\
\text { nephropathy }\end{array}$} & & $\begin{array}{l}\text { e, sex, donor age and } \\
\text { sex, type of dialysis, } \\
\text { ne in dialysis, number } \\
\text { of HLA mismatched } \\
\text { tigens, cold ischemia, } \\
\text { immunosuppressive } \\
\text { treatment, acute } \\
\text { rejection, chronic } \\
\text { llograft nephropathy }\end{array}$ \\
\hline $\begin{array}{l}\text { Astrup } \\
\text { et al. [26] }\end{array}$ & \multicolumn{2}{|c|}{$\begin{array}{l}\text { Biotintyramin-amplified } \\
\text { enzyme immunoassay }\end{array}$} & \multicolumn{3}{|c|}{12.6} & \multicolumn{2}{|c|}{$\begin{array}{c}\text { All-cause mortality, } \\
\text { cardiovascular } \\
\text { mortality }\end{array}$} & & $\begin{array}{l}\text { ge, cholesterol, } \mathrm{HbA}_{1 \mathrm{c}} \text {, } \\
\mathrm{Cr}\end{array}$ \\
\hline $\begin{array}{l}\text { Etter } \\
\text { et al. [32] }\end{array}$ & \multicolumn{2}{|r|}{ TRACE } & \multicolumn{2}{|r|}{24} & & \multicolumn{2}{|c|}{ All-cause mortality } & & $\begin{array}{l}\text { Age, sex, number of } \\
\text { omorbidities, dialysis } \\
\text { ntage, Kt/V, IL-6, CRP, } \\
\text { PTH, Ca } \mathrm{PO}_{4} \text { product, } \\
\text { cholesterol }\end{array}$ \\
\hline $\begin{array}{l}\text { Kalousova } \\
\text { et al. [29] }\end{array}$ & \multicolumn{2}{|r|}{ TRACE } & \multicolumn{2}{|r|}{30.8} & & \multicolumn{2}{|c|}{$\begin{array}{l}\text { All-cause mortality, } \\
\text { cardiovascular } \\
\text { mortality, infectious } \\
\text { mortality }\end{array}$} & & $\begin{array}{l}\text { De, sex, hypertension, } \\
\text { DM, smoking, BMI, } \\
\text { CVD, IGF, MMPS, } \\
\text { transplantation, } \\
\text { cTnI, BNP, albumin, } \\
\text { cholesterol, CRP, } \\
\text { rosomucoid, retinol, } \\
\text { phosphate, PTH }\end{array}$ \\
\hline $\begin{array}{l}\text { Kalousova } \\
\text { et al. [30] }\end{array}$ & \multicolumn{2}{|r|}{ TRACE } & \multicolumn{2}{|r|}{20.9} & & \multicolumn{2}{|c|}{$\begin{array}{l}\text { All-cause mortality, } \\
\text { cardiovascular events, } \\
\text { infectious mortality }\end{array}$} & & $\begin{array}{l}\text { Age, sex, smoking, } \\
\text { MI, atorvasatin, CVD, } \\
\text { SBP, dialysis vintage, } \\
\text { olesterol, Cr, albumin, } \\
\text { osphate, hemoglobin }\end{array}$ \\
\hline $\begin{array}{l}\text { Jefferies } \\
\text { et al. [28] }\end{array}$ & \multicolumn{2}{|c|}{$\begin{array}{l}\text { Immunofluorometric } \\
\text { assays }\end{array}$} & \multicolumn{2}{|r|}{3.45} & & \multicolumn{2}{|c|}{ All-cause mortality } & & $\begin{array}{c}\text { Age, } c \operatorname{TnT} \text {, dialysis } \\
\text { vintage }\end{array}$ \\
\hline
\end{tabular}

$B M I$ - body mass index, BNP - B type natriuretic peptide, CKD - chronic kidney disease, Cr - creatinine, CRP - C-reactive protein, CTnl - cardiac troponin T, CVD - cardiovascular disease, DM - diabetes mellitus, DSL - Diagnositc Systems Laboratory, $F$ - female, $M$ - male, ELISA - enzyme-linked immunosorbent assay, HLA - human leukocyte antigen, IGF-insulin-like growth factor, IL - interleukine, $M M P$ - matrix metalloproteinase, NA - not available, PAPP-A - pregnancy-associated plasma protein A, PTH - parathyroid hormone, SBP - systolic blood pressure, TnT - troponin T. TRACE - Time Resolved Amplified Cryptate Emission. 
to 1098. The average age range was from 53 to 70 years. The male proportion ranged from $46.7 \%$ to $70.9 \%$. Four studies were performed in dialysis patients [28-30, 32], 1 study was performed in patients with diabetic nephropathy [26] and 1 study was performed in patients with ESRD waiting for kidney transplantation [31]. The duration of follow-up were varied from 3 months to 5 years. Serum PAPP-A was measured by TRACE in 3 studies $[29,30,32]$, and by other methods in 3 studies [26, 28, 31]. PAPP-A values were obtained by a cut-off value in 4 studies $[26,29,31$, 32], by quartiles in 1 study [30] and the median value in 1 study [28] (Figure 1).

\section{Main analysis}

Comparing the group with lowest levels of serum PAPP-A, the pooled RR for all-cause mortality was $1.50(95 \% \mathrm{Cl}: 1.17-1.92, p=0.001$; $R^{2}=76.2 \%, p$ for heterogeneity $=0.002$ ) (Figure $2 \mathrm{~A}$ ). For the endpoint of cardiovascular events, the pooled RR was 1.26 (95\% Cl: 0.95-1.69, $p=$
1866 Articles identified through databases searches

1838 excluded based on abstract and titles

28 Potential articles for detailed evaluations

3 Not prospective design 18 Not relevant to the outcomes of interest 1 Not providing multi-variable adjusted RRs

6 Articles included in the meta-analysis

5 reported the risk of all-cause mortality

4 reported the risk of cardiovascular events

Figure 1. Flow chart of the trial selection process $R R$ - relative risk.

$0.113 ; P^{2}=65.8 \%, p$ for heterogeneity $=0.032$ ) (Figure $2 \mathrm{~B}$ ).

To clarify the heterogeneity, we performed sensitivity analysis by excluding each individual study at a time (Table II). The sensitivity analysis also showed that the positive relationship between el-

A

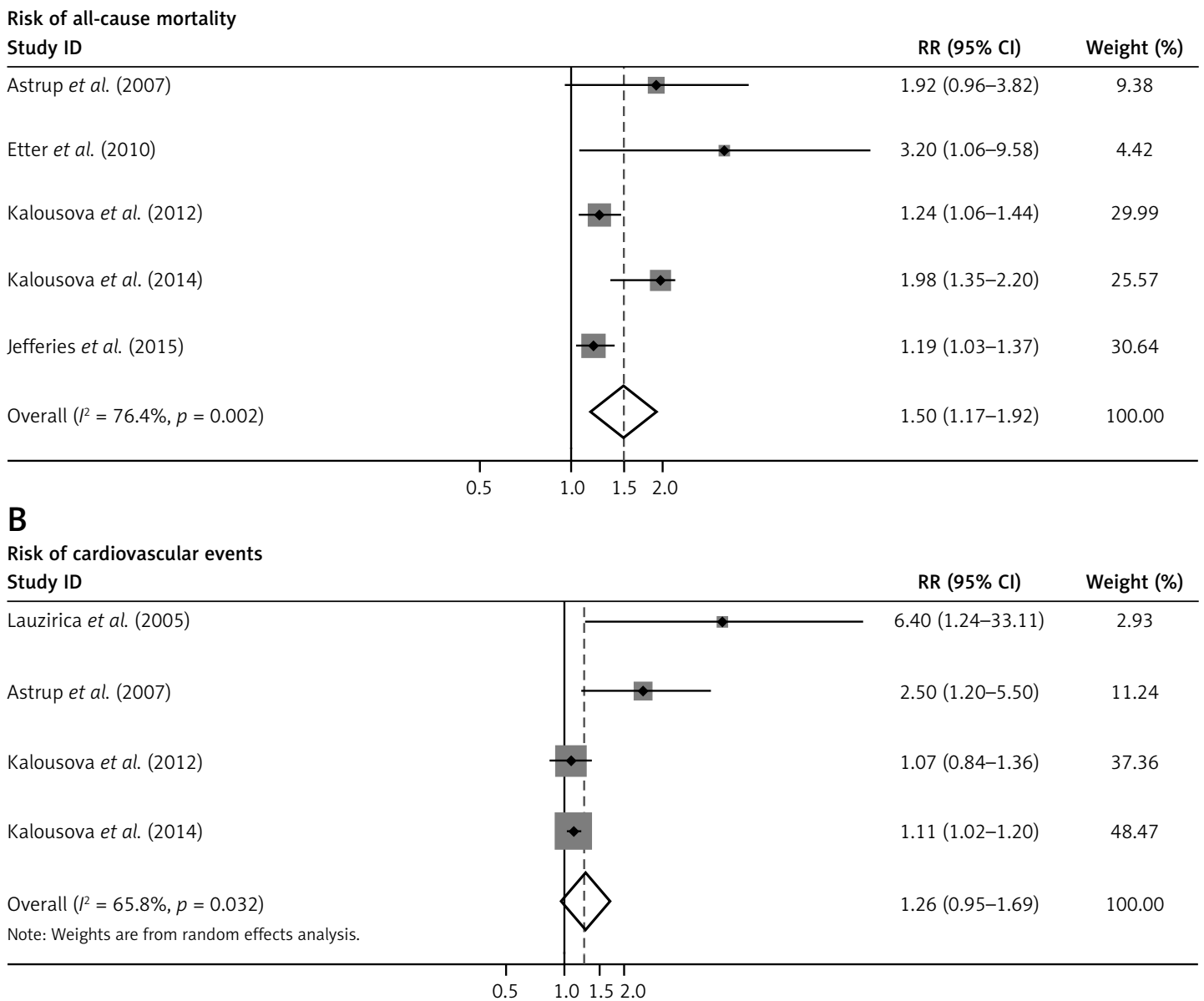

Figure 2. Elevated serum PAPP-A and risk of all-cause mortality, cardiovascular events and mortality due to infection. Meta-analysis of the highest vs. lowest serum PAPP-A for (A) risk of all-cause mortality; (B) risk of cardiovascular events

$\mathrm{Cl}$ - confidence interval, PAPP-A - pregnancy-associated plasma protein $A, R R$ - relative risk. 
Table II. Sensitivity analysis excluding one study at a time (all-cause mortality)

\begin{tabular}{|lccccc|}
\hline Excluding study & Year & Pooled RR (95\% Cl) & $I^{2}(\%)$ & $\mathrm{Pa}$ & $\mathrm{Pb}$ \\
\hline Astrup et al. & 2007 & $1.31(1.20-1.45)$ & 81.1 & 0.001 & 0.000 \\
\hline Etter et al. & 2010 & $1.32(1.20-1.47)$ & 79.3 & 0.002 & 0.000 \\
\hline Kalousova et al. & 2012 & $1.38(1.22-1.55)$ & 81.0 & 0.001 & 0.000 \\
\hline Kalousova et al. & 2014 & $1.23(1.11-1.37)$ & 36.2 & 0.20 & 0.000 \\
\hline Jefferies et al. & 2015 & $1.47(1.27-1.64)$ & 76.8 & 0.005 & 0.000 \\
\hline
\end{tabular}

Table III. Subgroup analysis

\begin{tabular}{|c|c|c|c|c|}
\hline \multirow[t]{2}{*}{ Characteristic } & \multicolumn{4}{|c|}{ All-cause mortality } \\
\hline & Data points, $N$ & Pooled RR $(95 \% \mathrm{Cl})$ & $P$ for heterogeneity & $\begin{array}{l}P \text { for subgroup } \\
\text { difference }\end{array}$ \\
\hline All studies & 5 & $1.50(1.17-1.92)$ & 0.002 & \\
\hline \multicolumn{5}{|l|}{ Age [years]: } \\
\hline$<65$ & 2 & $1.34(0.96-1.90)$ & 0.223 & 0.44 \\
\hline$\geq 65$ & 3 & $1.68(1.04$ to 2.70$)$ & 0.001 & \\
\hline \multicolumn{5}{|c|}{ Male proportion: } \\
\hline$<60 \%$ & 2 & $1.60(0.94-2.71)$ & 0.001 & 0.15 \\
\hline$\geq 60 \%$ & 3 & $1.55(0.97-2.46)$ & 0.0 .95 & \\
\hline \multicolumn{5}{|c|}{ Follow-up term [years]: } \\
\hline$<5$ & 3 & $1.68(1.04-2.70)$ & 0.001 & 0.44 \\
\hline$\geq 5$ & 2 & $1.34(0.96-1.90)$ & 0.223 & \\
\hline \multicolumn{5}{|c|}{ Assay for PAPP-A: } \\
\hline TRACE & 3 & $1.69(1.09-2.64)$ & 0.183 & 0.06 \\
\hline Other & 2 & $1.34(0.89-1.99)$ & 0.223 & \\
\hline
\end{tabular}

PAPP-A - pregnancy-associated plasma protein A, RR - relative risk, TRACE - Time Resolved Amplified Cryptate Emission.

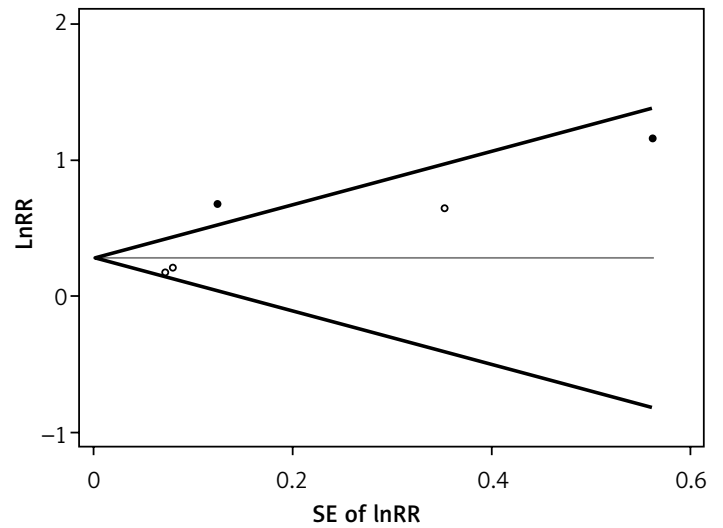

Figure 3. Begg's funnel plot (with pseudo $95 \% \mathrm{Cls}$ ) of the studies in the meta-analysis. Studies that reported the elevated serum PAPP-A and the risk of all-cause mortality were plotted with $\ln R R$ on the vertical axis and the SEs of the InRR along the horizontal axis

PAPP-A - pregnancy-associated plasma protein $A, R R-r e$ lative risk, SEs - standard errors. evated circulation PAPP-A and the risk of all-cause mortality was not modified by excluding each individual study at a time. Furthermore, we conducted subgroup analysis to explore the potential sources of heterogeneity according to the specified characteristics. As shown in Table III, age, male proportion, follow-up term and the assay methods of serum PAPP-A were not modifiable factors to the relevant endpoint of all-cause mortality.

\section{Publication bias}

No evidence of publication bias was observed in Begg's funnel plot. The results was further confirmed in Begg's adjusted rank correlation test $(p=0.221)$ and Egger's regression test $(p=0.176)$ for the association of elevated serum PAPP-A with all-cause mortality (Figure 3 ).

\section{Discussion}

To the best of our knowledge, this is the first meta-analysis which has systematically reviewed 
the association between circulating elevated PAPP-A and the risk of all-cause mortality and cardiovascular events in patients with CKD. In the meta-analysis of prospective studies, we found that elevated serum PAPP-A was associated with 1.50-folder higher risk of all-cause mortality for the patients with renal dysfunction. The relationship of serum PAPP-A and the risk of all-cause mortality was not modified by age, male proportion, follow-up term or the assay methods of serum PAPP-A. There seemed to be a positive association between elevated serum PAPP-A and cardiovascular events, but it was not statistically significant.

Previous studies about the relationship between circulating PAPP-A and prognosis of CKD patients are inconsistent. Some trials have reported a positive association between serum PAPP-A and the risk of death, while others have reported no association [26-32]. We combined all available trials and found a positive association of circulating PAPP-A and the risk of all-cause mortality. Our findings supported the previous meta-analysis which reported that elevated serum PAPP-A was an independent risk factor for all-cause mortality in patients with coronary heart disease [24]. Furthermore, our sensitivity analysis showed that the positive association of the serum PAPP-A and the risk of all-cause mortality was not influenced by excluding each individual study at a time, which strengthened the statistical power. CKD, especially ESRD, are known as a heavy burden with high mortality, morbidity and economic cost. Therefore, it is helpful to identify the biomarkers for risk stratification and prognosis analysis. All of the included trials have controlled numerous factors such as age, gender, serum cholesterol, creatinine and dialysis parameter. We used the most fully adjusted results and found that elevated serum PAPP-A was an independent risk factor for allcause mortality in patients with CKD.

Heterogeneity is often a concern of a metaanalysis. Although there was significant heterogeneity among the included studies, the sensitivity analysis showed that the main results were not influenced. Furthermore, our subgroup analysis indicated that age, male proportion, follow-up term and assay methods for measuring PAPP-A were not modifiable factors. Nevertheless, large-scale prospective studies are needed to verify the potential factors influencing the association between circulating PAPP-A and all-cause mortality.

It was not fully understood about the elevated serum PAPP-A in predicting adverse events in CKD patients. First, clinical studies have reported that serum PAPP-A is not only correlated with serum level of creatinine, a marker of renal function, but is also correlated with other inflammatory factors, such as C-reactive protein, cytokine tumor necrosis factor $\alpha$ and interleukin $1 \beta$ in patients with renal disease [31, 36-39]. Second, in vivo studies have indicated that the animal model with PAPP-A gene knock-out was less likely to suffer from nephropathy compared with the wild type in old age $[40,41]$. The mouse model without PAPP-A gene expression could resist the development of diabetic nephropathy [42]. Third, in vitro studies have suggested that inflammation cytokine tumor necrosis factor $\alpha$ and interleukin $1 \beta$ could stimulate PAPP-A gene expression in human mesangial cells, indicating that the kidney may be another target organ of PAPP-A [43]. Two included trials have reported that serum PAPP-A was associated with high risk of infectious mortality in CKD patients, which may be an important cause of death $[29,30]$. Fourth, PAPP-A is an important metalloprotein involved in the progression of atherosclerosis [8]. Elevated serum PAPP-A was correlated with the severity of the plaque load [44]. Accelerated atherosclerosis is an important cause of the adverse prognosis in patients with CKD $[2,4,45,46]$. Our meta-analysis indicated that circulating PAPP-A seemed to be associated with the risk of cardiac events in the CKD patients, but it was not statistically significant. Restricted by the number of included trials and heterogeneity, it needs further exploration in experimental studies and large-scale prospective studies for PAPP-A in predicting cardiovascular events in CKD patients in future.

Our study has a few limitations. First, the residual confounders may be potential confounders. Most included studies have adjusted for a wide range of potential confounders. However, we could not exclude other confounders which might have influenced the results. For example, serum PAPP-A level might be affected by heparin administration. Three included trials [28-30] have indicated that blood samples were collected before heparin administration while others did not. So it needs further evaluation whether heparin administration is a modifiable factor for the predictive value of serum of PAPP-A. Previous history of coronary artery disease may also be a modifiable factor for the prognosis. We could not perform a subgroup analysis according to the percentage of previous history of coronary artery disease because only three studies have provided the relative data $[26,29,30]$. Second, restricted by the number of included trials, the predictive value of serum PAPP-A in cardiovascular events and all-cause mortality needs further exploration in future studies. Third, the results may be influenced by study design, but we did not find that the predictive value of PAPP-A was influenced by age, male proportion, duration of follow-up or assay methods. Fourth, all of the included studies had different cut-off values of serum PAPP-A. Given the nature of a meta-analysis, we could not provide the cut-off value of serum PAPP-A. Fifth, 
necrosis factor $\alpha$ and interleukin $1 \beta$ are stimulators of PAPP-A. However, we could not compare serum PAPP-A with tumor necrosis factor $\alpha$ and interleukin $1 \beta$ about the predictive value because only two included trials have provided the relative data about tumor necrosis factor $\alpha$ and interleukin $1 \beta$. Finally, publication bias could be a concern, but we found no evidence of publication bias.

In conclusion, elevated serum PAPP-A was associated with higher risk of all-cause mortality in patients with CKD. The independent predictive value of PAPP-A was not affected by age, male proportion, duration of follow-up term or assay methods. How PAPP-A was involved in kidney disease and whether serum PAPP-A is a candidate biomarker for prognosis of renal dysfunction needs further exploration in numerous experimental and largescale clinical trials.

\section{Acknowledgments}

This work was supported by the National Key Research and Development Plan of China (2016YFC1300100) and CAMS Innovation Fund for Medical Sciences (CIFMS) (2016-I2M-1-002).

\section{Conflict of interest}

The authors declare no conflict of interest.

\section{References}

1. Lozano R, Naghavi M, Foreman K, et al. Global and regional mortality from 235 causes of death for 20 age groups in 1990 and 2010: a systematic analysis for the Global Burden of Disease Study 2010. Lancet 2012; 380: 2095-128.

2. Thompson $\mathrm{S}$, James $\mathrm{M}$, Wiebe $\mathrm{N}$, et al. Cause of death in patients with reduced kidney function. J Am Soc Nephrol 2015; 26: 2504-11.

3. Tonelli M, Muntner P, Lloyd A, et al. Risk of coronary events in people with chronic kidney disease compared with those with diabetes: a population-level cohort study. Lancet 2012; 380: 807-14.

4. Sud M, Tangri N, Pintilie M, Levey AS, Naimark D. Risk of end-stage renal disease and death after cardiovascular events in chronic kidney disease. Circulation 2014; 130: 458-65.

5. Schefold JC, Filippatos G, Hasenfuss G, Anker SD, von Haehling S. Heart failure and kidney dysfunction: epidemiology, mechanisms and management. Nat Rev Nephrol 2016; 12: 610-23.

6. Sud M, Naimark DM. Cardiovascular disease in chronic kidney disease in 2015. Curr Opin Nephrol Hypertens 2016; 25: 203-7.

7. Rubenstein MH, Harrell LC, Sheynberg BV, Schunkert H, Bazari $\mathrm{H}$, Palacios IF. Are patients with renal failure good candidates for percutaneous coronary revascularization in the new device era? Circulation 2000; 102: 2966-72.

8. Harrington SC, Simari RD, Conover CA. Genetic deletion of pregnancy-associated plasma protein-A is associated with resistance to atherosclerotic lesion development in apolipoprotein E-deficient mice challenged with a highfat diet. Circ Res 2007; 100: 1696-702.
9. Resch ZT, Chen BK, Bale LK, Oxvig C, Overgaard MT, Conover CA. Pregnancy-associated plasma protein a gene expression as a target of inflammatory cytokines. Endocrinology 2004; 145: 1124-9.

10. Conover CA, Bale LK, Harrington SC, Resch ZT, Overgaard MT, Oxvig C. Cytokine stimulation of pregnancyassociated plasma protein A expression in human coronary artery smooth muscle cells: inhibition by resveratrol. Am J Physiol Cell Physiol 2006; 290: C183-8.

11. Boldt HB, Conover CA. Pregnancy-associated plasma protein-A (PAPP-A): a local regulator of IGF bioavailability through cleavage of IGFBPs. Growth Horm IGF Res 2007; 17: 10-8

12. Conover CA, Harrington SC, Bale LK. Differential regulation of pregnancy associated plasma protein-A in human coronary artery endothelial cells and smooth muscle cells. Growth Horm IGF Res 2008; 18: 213-20.

13. Conover CA, Mason MA, Bale LK, et al. Transgenic overexpression of pregnancy-associated plasma protein-A in murine arterial smooth muscle accelerates atherosclerotic lesion development. Am J Physiol Heart Circ Physiol 2010; 299: H284-91.

14. Iversen KK, Teisner AS, Teisner B, et al. Pregnancy associated plasma protein $\mathrm{A}$, a potential marker for vulnerable plaque in patients with non-ST-segment elevation acute coronary syndrome. Clin Biochem 2009; 42: 828-34.

15. Bayes-Genis A, Conover CA, Overgaard MT, et al. Pregnancy-associated plasma protein $A$ as a marker of acute coronary syndromes. N Engl J Med 2001; 345: 1022-9.

16. Heeschen C, Dimmeler S, Hamm CW, Fichtlscherer S, Simoons ML, Zeiher AM. Pregnancy-associated plasma protein-A levels in patients with acute coronary syndromes: comparison with markers of systemic inflammation, platelet activation, and myocardial necrosis. J Am Coll Cardiol 2005; 45: 229-37.

17. Iversen KK, Teisner B, Winkel P, et al. Pregnancy associated plasma protein-A as a marker for myocardial infarction and death in patients with stable coronary artery disease: a prognostic study within the CLARICOR Trial. Atherosclerosis 2011; 214: 203-8.

18. Kavsak PA, Wang X, Henderson M, Ko DT, MacRae AR, Jaffe AS. PAPP-A as a marker of increased long-term risk in patients with chest pain. Clin Biochem 2009; 42: 1012-8.

19. Lund J, Wittfooth S, Qin QP, et al. Free vs total pregnancy-associated plasma protein A (PAPP-A) as a predictor of 1-year outcome in patients presenting with non-ST-elevation acute coronary syndrome. Clin Chem 2010; 56: 1158-65.

20. Lund J, Qin QP, Ilva T, et al. Circulating pregnancy-associated plasma protein a predicts outcome in patients with acute coronary syndrome but no troponin I elevation. Circulation 2003; 108: 1924-6.

21. Elesber AA, Conover CA, Denktas AE, et al. Prognostic value of circulating pregnancy-associated plasma protein levels in patients with chronic stable angina. Eur Heart J 2006; 27: 1678-84.

22. Mei WY, Du ZM, Zhao Q, et al. Pregnancy-associated plasma protein predicts outcomes of percutaneous coronary intervention in patients with non-ST-elevation acute coronary syndrome. Heart Lung 2011; 40: e78-83.

23. Bonaca MP, Scirica BM, Sabatine MS, et al. Prospective evaluation of pregnancy-associated plasma protein-a and outcomes in patients with acute coronary syndromes. J Am Coll Cardiol 2012; 60: 332-8.

24. Li Y, Zhou C, Zhou X, Li L, Hui R. Pregnancy-associated plasma protein $A$ predicts adverse vascular events in 
patients with coronary heart disease: a systematic re view and meta-analysis. Arch Med Sci 2013; 9: 389-97.

25. Li Y, Zhou C, Zhou X, Song L, Hui R. PAPP-A in cardiac and non-cardiac conditions. Clin Chim Acta 2013; 417: 67-72.

26. Astrup AS, Tarnow L, Christiansen M, Hansen PR, Parving $\mathrm{HH}$, Rossing P. Pregnancy-associated plasma protein A in a large cohort of Type 1 diabetic patients with and without diabetic nephropathy - a prospective follow-up study. Diabet Med 2007; 24: 1381-5.

27. Bayes B, Granada ML, Pastor MC, et al. Obesity, adiponectin and inflammation as predictors of new-onset diabetes mellitus after kidney transplantation. Am J Transplant 2007; 7: 416-22.

28. Jefferies HJ, Tertti R, Wittfooth S, et al. Elevated serum free pregnancy-associated plasma protein-A independently predicts mortality in haemodialysis patients but is not associated with recurrent haemodialysis-induced ischaemic myocardial injury. Nephron 2015; 129: 171-8.

29. Kalousova M, Benakova H, Kubena AA, Dusilova-Sulkova S, Tesar V, Zima T. Pregnancy-associated plasma protein $A$ as an independent mortality predictor in long term hemodialysis patients. Kidney Blood Press Res 2012; 35: 192-201.

30. Kalousova M, Zima T, Krane V, et al. Pregnancy-associated plasma protein $\mathrm{A}$ associates with cardiovascular events in diabetic hemodialysis patients. Atherosclerosis 2014; 236: 263-9.

31. Lauzurica R, Pastor C, Bayes B, Hernandez JM, Romero R. Pretransplant pregnancy-associated plasma protein-a as a predictor of chronic allograft nephropathy and posttransplant cardiovascular events. Transplantation 2005; 80: 1441-6.

32. Etter C, Straub Y, Hersberger M, et al. Pregnancy-associated plasma protein-A is an independent short-time predictor of mortality in patients on maintenance haemodialysis. Eur Heart J 2010; 31: 354-9.

33. Stroup DF, Berlin JA, Morton SC, et al. Meta-analysis of observational studies in epidemiology: a proposal for reporting. Meta-analysis Of Observational Studies in Epidemiology (MOOSE) group. JAMA 2000; 283: 2008-12.

34. DerSimonian R, Laird N. Meta-analysis in clinical trials. Control Clin Trials 1986; 7: 177-88.

35. Egger M, Davey Smith G, Schneider M, Minder C. Bias in meta-analysis detected by a simple, graphical test. BMJ 1997; 315: 629-34.

36. Fialova L, Kalousova M, Soukupova J, et al. Relationship of pregnancy-associated plasma protein-a to renal function and dialysis modalities. Kidney Blood Press Res 2004; 27: 88-95

37. Coskun A, Duran S, Apaydin S, Bulut I, Sariyar M. Pregnancy-associated plasma protein-A: evaluation of a new biomarker in renal transplant patients. Transplant Proc 2007; 39: 3072-6.

38. Lukaszyk E, Lukaszyk M, Koc-Zorawska E, Bodzenta-Lukaszyk A, Malyszko J. Fibroblast growth factor 23, iron and inflammation - are they related in early stages of chronic kidney disease? Arch Med Sci 2016; 13: 845-50.

39. Fadel FI, Elshamaa MF, Elghoroury EA, et al. Usefulness of serum procalcitonin as a diagnostic biomarker of infection in children with chronic kidney disease. Arch Med Sci Atheroscler Dis 2016; 1: 23-31.

40. Conover CA, Bale LK, Mader JR, Mason MA, Keenan KP, Marler RJ. Longevity and age-related pathology of mice deficient in pregnancy-associated plasma protein-A. J Gerontol A Biol Sci Med Sci 2010; 65: 590-9.

41. Swindell WR, Masternak MM, Bartke A. In vivo analysis of gene expression in long-lived mice lacking the preg- nancy-associated plasma protein A (PappA) gene. Exp Gerontol 2010; 45: 366-74.

42. Mader JR, Resch ZT, McLean GR, et al. Mice deficient in PAPP-A show resistance to the development of diabetic nephropathy. J Endocrinol 2013; 219: 51-8.

43. Donegan D, Bale LK, Conover CA. PAPP-A in normal human mesangial cells: effect of inflammation and factors related to diabetic nephropathy. J Endocrinol 2016; 231: 71-80.

44. Cosin-Sales J, Kaski JC, Christiansen M, et al. Relationship among pregnancy associated plasma protein-A levels, clinical characteristics, and coronary artery disease extent in patients with chronic stable angina pectoris. Eur Heart J 2005; 26: 2093-8.

45. Rysz-Górzyńska M, Banach M. Subfractions of high-density lipoprotein (HDL) and dysfunctional HDL in chronic kidney disease patients. Arch Med Sci 2016; 12: 844-9.

46. Căpuşă C, Stefan G, Stancu S, Ilyes A, Dorobanțu N, Mircescu G. Subclinical cardiovascular disease markers and vitamin $D$ deficiency in non-dialysis chronic kidney disease patients. Arch Med Sci 2016; 12: 1015-22. 